\title{
Corrosion performances of polyaniline and poly(N-methylaniline) coated stainless steel by impedance spectroscopy
}

\author{
Aziz Yă̆an \\ Chemistry Education, Dicle University, 21280, Diyarbakır, Turkey \\ E-mail: yagan@dicle.edu.tr
}

doi: $10.20964 / 2019.03 .77$

Received: 4 November 2018 / Accepted: 21 December 2018 / Published: 7 February 2019

\begin{abstract}
Electrochemical depositions of polyaniline (PAni) and poly(N-methylaniline) (PNMA) coatings on 304 stainless steel (SS) electrodes were carried out potentiodynamically between $-0.2 \mathrm{~V}$ and $1.1 \mathrm{~V}$ vs SCE with a scan rate of $20 \mathrm{mV} / \mathrm{s}$ by using cyclic voltammetry technique from aqueous oxalic acid electrolyte solution. Properties of adhesive and electroactive PNMA coatings were successfully investigated using cyclic voltammetry tecnique. On the other hand, electrochemical impedance spectroscopy (EIS) was used to investigate long-term corrosion performance of PAni and PNMA coated electrodes separately in $0.5 \mathrm{M} \mathrm{NaCl}$ and $0.5 \mathrm{M} \mathrm{HCl}$ solutions. EIS measurement results showed that PAni and PNMA coatings improved the protection for SS in neutral and acidic corrosive solutions. Also, PAni and PNMA coatings were able to offer the protection to SS electrodes for longer immersion period in $\mathrm{NaCl}$ solution when compared to $\mathrm{HCl}$. While PAni coating on steel was insufficient to prevent corrosion after 168 hours of immersion in $\mathrm{NaCl}$, PNMA coating lost its protective properties after 240 hours.
\end{abstract}

Keywords: Electrochemical synthesis, Polyaniline, Poly(N-methylaniline), Stainless steel, Impedance spectroscopy

\section{$\underline{\text { FULL TEXT }}$}

(C) 2019 The Authors. Published by ESG (www.electrochemsci.org). This article is an open access article distributed under the terms and conditions of the Creative Commons Attribution license (http://creativecommons.org/licenses/by/4.0/). 